\title{
Communication
}

[Comunicação]

\section{A molecular survey reveals high occurrence of co-infections in intensive pork production farms with increased rates of mummified swine fetuses in Southern Brazil}

\author{
[Pesquisa molecular revela alta ocorrência de coinfecções em granjas de produção intensiva \\ de suínos com altas taxas de mumificação fetal no sul do Brasil] \\ K.C. Cezario ${ }^{1}$, P.E. Bennemann ${ }^{2}$, J.M. Maciel $^{2}$, G. Herdt ${ }^{3}$, M. Martins ${ }^{2}$, \\ A.A. Tonin 4 , A.M. Prestes ${ }^{2}$, S.A. Machado ${ }^{2 *}$ \\ ${ }^{1}$ Aluna de pós-graduação - Universidade do Oeste de Santa Catarina - Xanxerê, SC \\ ${ }^{2}$ Universidade do Oeste de Santa Catarina - Xanxerê, SC \\ ${ }^{3}$ Aluna de graduação - Universidade do Oeste de Santa Catarina - Xanxerê, SC \\ ${ }^{4}$ Instituto Federal de Educação, Ciência e Tecnologia do Amazonas - Manaus, AM
}

\begin{abstract}
Despite intensive farming and genetic improvement, reproductive failure still has a negative impact on swine production (Vargas et al., 2007). Embryonic and fetal mortality may be associated with porcine parvovirus (PPV), porcine circovirus 2 (PCV2) and Leptospira spp. (Kim et al., 2003; Segalés, 2012; Herdt et al., 2019). Although the information on the pathogenesis of porcine circovirus 3 (PCV3) is still limited, this virus has been recently described in mummified fetuses as the sole pathogen present (Palinski et al., 2017). Moreover, PCV3 has been consistently identified in fetal tissues from mummified fetuses harvested from farms in Southern Brazil (Dal Santo et al., 2020).
\end{abstract}

Current information on infectious causes of fetal mummification is important to aid animal health care practitioners and producers in strategic farm planning to control and prevent these reproductive disorders, considering increasing rates of fetal mummification in recent years (personal communication). Therefore, our goal was to investigate the presence of PPV, PCV2, PCV3, and pathogenic leptospires in samples of mummified swine fetuses obtained from intensive pork production farms in Southern Brazil. We also assessed the age of the gestational loss and occurrence of fetal mummification according to parity order.

The samples were collected only from sow farms $(\mathrm{n}=8)$ with fetal mummification rates $\geq 2.5 \%$ from selected females of different parity orders that delivered two or more mummified fetuses. The fetal samples were individually packed in identified plastic bags and stored at $-20^{\circ} \mathrm{C}$ until laboratory processing, which included measurements of linear size and weight, followed by aseptic collection of organ fragments. Biometrical data and its relationship with gestational age of fetal death was carried out according to Straw et al. (1999). Samples of lung, kidney, liver, and heart were harvested, and pooled for DNA extraction using a tissue homogenizer $(100 \mathrm{mg}$ of tissue in $500 \mu \mathrm{L}$ of TrisEDTA buffer [10mM Tris. HCl, $1 \mathrm{mM}$ EDTA, $\mathrm{pH}$ 8]) and silica-binding chemistry according to manufacturer's instructions (Biopur Mini Spin Plus Extraction Kit, Mobius Life Science, Brazil). Then, the total DNA was eluted in $200 \mu \mathrm{L}$ of DNase/RNase free water and stored at $-20^{\circ} \mathrm{C}$ until $\mathrm{PCR}$ reaction. We used conserved genome targets for PCR detection of PPV (NS-1; Soares et al., 1999), PCV2 (ORF2; Monroy et al., 2014), and PCV3 (ORF2; Palinski et al., 2017).

For detection of pathogenic leptospires, well established virulence factors $\operatorname{LigA}$ and $\operatorname{LigB}$ genes of Leptospira spp. (Palaniappan et al., 2005) were used. DNA amplification was performed in a reaction containing $12.5 \mu \mathrm{L}$ of GoTaq® Green (GoTaq Green Master Mix, Promega), two $\mu \mathrm{L}$ of DNA, primers, and nuclease free water to a final volume of $25 \mu \mathrm{L}$. PCR for

Recebido em 22 de outubro de 2020

Aceito em 12 de março de 2021

*Autor para correspondência (corresponding author)

E-mail: sergio.machado@unoesc.edu.br 
PPV, PCV2, PCV3, and Leptospira spp. were performed according to Monroy et al. (2014), Palinski et al. (2017), Soares et al. (1999), and Palaniappan et al. (2005), respectively. We included negative (no template control) and positive controls with purified DNA of known positive samples. For nucleic acid staining, three $\mu \mathrm{L}$ (1:500 dilution) of an intercalating agent (Unisafe Dye, Uniscience do Brasil, SP, Brazil) were used for each sample, then the PCR fragments were resolved on a $1 \%$ agarose gel and analyzed in a photo documentation system (ChemiDoc MP Gel Imaging System, Bio-Rad (USA)).

PCR analysis of 308 samples were classified according to the state of origin. A total of 87 samples $(28.25 \%)$ from Santa Catarina, 89 samples $(28.90 \%)$ from Paraná and 132 samples (42.86\%) from Rio Grande do Sul were tested. Regardless of the state, presence of coinfections was observed in most samples. The PCR results are depicted in Table 1 . We observed an exceptionally high rate of samples (96.75\%) positive for PCV3. Coinfections, especially with PCV3, were surprisingly prevalent (92.5\%). Table 2 illustrates the statistical difference between the presence of PCV3 and its associations with other agents, considering only samples positive for PCV3 $(\mathrm{n}=298)$. Most pregnancy losses were observed between days 50 and 70 of pregnancy, nevertheless parity order had neither relationship with pregnancy loss frequency nor number of mummified fetuses.

Table 1. Polymerase chain reaction (PCR) results for the four agents surveyed (PPV, PCV2 and PCV3 and Leptospira spp.) according to the region of origin of samples of mummified fetuses from sow farms in Southern Brazil.

\begin{tabular}{l|cccc}
\hline \multicolumn{1}{c}{ Surveyed Agent } & \multicolumn{4}{c}{ State of origin } \\
\cline { 2 - 5 } NEGATIVE & SC & PR & RS & TOTAL $(\%)$ \\
\hline PPV & 1 & 4 & 2 & $7(2.27)$ \\
PCV2 & - & - & 1 & $1(0.32)$ \\
PCV3 & - & - & 1 & $1(0.32)$ \\
Leptospira spp. & 5 & - & 8 & $13(4.22)$ \\
PPV+PCV2 & - & - & - & - \\
PPV+PCV3 & - & - & 1 & $1(0.32)$ \\
PPV+ Leptospira spp. & 12 & - & 13 & $25(8.12)$ \\
PCV2+PCV3 & - & - & - & - \\
PCV2+ Leptospira spp. & 18 & 56 & 25 & $99(32.14)$ \\
PCV3+ Leptospira spp. & - & - & - & - \\
PPV+PCV2+PCV3 & - & - & 2 & $2(0.64)$ \\
PCV2+PCV3+ Leptospira spp. & 45 & 29 & 62 & $136(44.16)$ \\
PPV+PCV3+ Leptospira spp. & 1 & - & 5 & $6(1.95)$ \\
PPV+PCV2+PCV3+ Leptospira spp. & 3 & - & 2 & $5(1, .62)$ \\
Total & 2 & - & 10 & $12(3.9)$ \\
\hline
\end{tabular}

Table 2. Infections with PCV3 and its associations with other agents in samples of mummified fetuses from sow farms in southern Brazil. Different superscripts represent significant differences $(\mathrm{P}<0.05)$.

\begin{tabular}{lc}
\hline Agents & Number of Mummified Fetuses $(\%)$ \\
\hline PCV3 & $13(4.37)^{\mathrm{cd}}$ \\
PPV+PCV3 & $25(8.39)^{\mathrm{c}}$ \\
PCV2+PCV3 & $99(33.22)^{\mathrm{b}}$ \\
PCV3+Leptospira spp. & $2(0.67)^{\mathrm{e}}$ \\
PPV+PCV2+PCV3 & $136(45.64)^{\mathrm{a}}$ \\
PCV2+PCV3+ Leptospira spp. & $6(2.01)^{\mathrm{de}}$ \\
PPV+PCV3+ Leptospira spp. & $5(1.68)^{\mathrm{de}}$ \\
PPV+PCV2+PCV3+ Leptospira spp. & $12(4.02)^{\mathrm{d}}$ \\
Total & $298(100)$ \\
\hline
\end{tabular}


Approximately $97.7 \%$ of the fetal samples tested were positive for at least one agent investigated in this study. Interestingly, PCV3 DNA was present in nearly all analyzed samples Although experimental evidence is still limited, PCV3 could not be ruled out as an important cause of pregnancy losses. Samples containing genomes of PPV, PCV2, and PCV3 alone or in any combination accounted for all positive results. PPV and PCV2 have worldwide distribution, contributing to fetal mummification if present in fetal tissues (Pescador et al., 2007; Maes et al., 2008), suggesting that fetal death occurs by intrauterine infection before the period of fetal immunocompetence. Intrauterine infection at 86, 92 and 93 days of gestation of seropositive sows caused fetal mummification, stillbirths and piglets with low viability, suggesting the involvement of PCV2 in fetal losses even in females with high antibody titers (Johnson et al., 2002).

We observed a high percentage of mummified fetuses positive for PCV2 $(82.79 \%)$, even in samples from vaccinated herds, which may indicate a possible breach in vaccination protocols. We also found a significant number of positive samples for PPV (58.4\%). Similarly, Wolf et al. (2008) found a positivity rate for PPV of $96.4 \%$ in fetuses collected from sow farms with a history of reproductive problems. Failure in vaccination protocols might range from improper handling of the vaccines to antigenic variation (Mészáros et al., 2017). For instance, vaccine issues due to change of viral surface glycoproteins, which alter host immune response might represent a much more difficult problem to circumvent and can take a long time to be corrected.

Coinfections were quite common, especially those of PPV and PCV2 (48.37\%). This finding might be of significance because macrophage infection with PPV can promote high levels of replication of PCV2, enhancing tissue damage (Kim et al., 2003). It is possible that the coinfections of parvo- and circoviruses - although little is known about the pathogenesis of PCV3 and its interplay with other agents - might increment morbidity in infected hosts. As can be noted, PCV3 is being highly reported in studies involving reproductive failure (Ku et al., 2017), digestive and respiratory diseases in pigs, besides nephropathic and dermatological swine syndrome (PDNS) (Palinski et al., 2017) and multisystemic inflammation (Phan et al., 2016). In our study, $96.75 \%(298 / 308)$ of the samples were positive for PCV3 demonstrating its high prevalence. Zhao et al. (2018) demonstrated that $70 \%$ of the samples were positive for PCV2 and PCV3, thus, it would be interesting to learn how the host's immune system respond to a co-infection of PCV2 and PCV3. Our results of indicate that only $25 / 308(8.11 \%)$ samples were infected by Leptospira spp. High concentration of modern facilities, biosecurity protocols and sanitation measures in farms of Southern Brazil may account for the low detection rates observed for Leptospira spp.

We observed a higher incidence of losses from 50 days of gestation. According to Segalés et al. (2013), the effects of parvovirus on the fetus are evident until approximately 60-70 days of gestation. In addition, Madson et al. (2009) confirmed the occurrence of reproductive problems with fetal death between 42 and 105 days of gestation, being a plausible reason for the data found in this study. Although fetal mummification was not related to parity order in our study, a revision in PCV vaccination protocols might be necessary aiming to decrease pregnancy losses. Currently, PCV2 pre- (90 days of pregnancy) or post-partum (eight to 10 days after delivery) vaccination of breeding sows are not in use.

Although the efficacy of PCV2 immunization in piglets is unquestionable, the effect of maternal immunity of sows on their newborns is still unclear. Apparently, there is no interference of maternal immunity on the performance of vaccinated piglets at four weeks of age (Fraile $e t$ al., 2012), however, to avoid the possibility of seroneutralization of maternal antibodies resulting from vaccination at three weeks of age and to protect the next pregnancy, we propose the use of an alternative PCV vaccine guideline, carried out between eight- and 10-days postpartum. This recommendation is supported by the involvement of PCV2 in embryo and fetal losses in swine.

High frequencies of PPV, PCV2 and PCV3 might provide enough evidence for the occurrence of mummifications seen in this work. Also, we observed a significant number of coinfections, considering high positive rates for more than one agent, which might operate in synergy to facilitate 
the establishment and development of the viral infections. Most gestational losses were observed among days 50 and 70 of pregnancy, which is consistent with the literature. Also, fetal mummification was distributed throughout a wide range of parity orders. In conclusion, special consideration should be given to PCV3 and its coinfections because it is a new and highly prevalent virus in our region. Also, our findings suggest that changes in current vaccination protocols should be carefully considered, especially regarding circoviruses.

Keywords: swine production, gestational losses, fetal mummification, porcine parvovirus, porcine circovirus, Leptospira spp.

\section{RESUMO}

Neste estudo, 308 amostras de fetos mumificados foram testadas para parvovírus suíno (PPV), circovírus suíno tipos 2 e 3 (PCV2 e PCV3) e leptospiras patogênicas. A idade gestacional no momento da perda gestacional e a frequência da mumificação fetal de acordo com a ordem de parto também foram investigadas. As amostras foram coletadas em granjas comerciais de criação de suínos da região sul do Brasil que apresentassem taxas de mumificação fetal igual ou maiores a 2,5\%. Fragmentos de pulmão, rim, fígado e coração de fetos suínos mumificados foram coletados para análise molecular. Resultados da PCR foram classificados de acordo com a região de origem das amostras, tendo Santa Catarina, Paraná e Rio Grande do Sul contabilizado 87 (28,25\%), 89 (28,90\%) e 132 (42,86\%) do total de amostras de fetos suínos mumificados, respectivamente. Coinfecções foram observadas na maioria dos casos e PCV3 foi o agente mais prevalente detectado, encontrado em 298 amostras (96,75\%). A maioria das perdas gestacionais foi observada entre 50 e 70 dias de gestação (168; 54,5\%) e a mumificação fetal não foi associada à ordem de parto das matrizes. Os achados sugerem que as altas taxas de fetos suínos mumificados na região Sul do Brasil podem ser explicadas pela infecção com esses agentes virais.

Palavras-chave: produção de suínos, perdas gestacionais, mumificação fetal, parvovírus suíno, circovírus suíno, Leptospira spp.

\section{ACKNOWLEDGEMENTS}

The authors thank the Nacional Council for the Improvement of Higher Education (CAPES) and the National Council for Scientific and Technological Development (CNPq), Grant No. 426532/2016-3 for their support. The authors declare, for all due purposes, that the project that gave rise to the present data does not require Institutional Animal Care and Use Committee (IACUC) approval because it did not use live animals.

\section{REFERENCES}

DAL SANTO, A.C.; CEZARIO, K.C.; BENNEMANN, P.E.; MACHADO, S.A. MARTINS, M. Full-genome sequences of porcine circovirus 3 (PCV3) and high prevalence in mummified fetuses from commercial farms in Brazil. Microbial. Pathog., v.141, p.104027, 2020.
FRAILE, L.; GRAU-ROMA, L.; SARASOLA, P. et al. Inactivated PCV2 one shot vaccine applied in 3-week-old piglets: Improvement of production parameters and interaction with maternally derived immunity. Vaccine, v.30, p.1986-1992, 2012.

HERDT, G.; MACIEL, A.E.; MARTINS, M. et al. High prevalence of porcine circovirus 2, porcine parvovirus, and pathogenic leptospires in mummified swine fetuses in Southern Brazil. Cienc. Rural, v.49, p.2-7, 2019.

JOHNSON, C.S.; JOO, H.S.; DIREKSIN, K.; YOON, K.; CHOI, Y.K. Experimental in utero inoculation of late-term swine fetuses with porcine circovirus type 2. J. Vet. Diagn. Invest., v.14, p.507-512, 2002.

KIM, J.; HAN, D.U.; CHOI, C.; CHAE, C. Simultaneous detection and differentiation between porcine circovirus and porcine parvovirus in boar semen by multiplex seminested polymerase chain reaction. J. Vet. Med. Sci., v.65, p.741-744, 2003. 
KU, X.; CHEN, F.; LI, P. et al. Identification and genetic characterization of porcine circovirus type 3 in China. Transbound. Emerg. Dis., v.64, p.703708, 2017.

MADSON, D.M.; PATTERSON, A.R.; RAMAMOORTHY, S. et al. Reproductive failure experimentally induced in sows via artificial insemination with semen spiked with porcine circovirus type 2. Vet. Pathol., v.46, p.707-716, 2009.

MAES, D.; NAUWYNCK, H.; RIJSSELAERE, T. et al. Diseases in swine transmitted by artificial insemination: an overview. Theriogenology, v.70, p.1337-1345, 2008.

MÉSZÁROS, I.; OLASZ, F.; CSÁGOLA, A.; TIJSSEN, P.; ZÁDORI, Z. Biology of porcine parvovirus (ungulate parvovirus 1). Viruses, v.9, p.393, 2017.

MONROY, M.A.; RAMIREZ-NIETO, G.C.; VERA, V.J.; CORREA, J.J.; MOGOLLÓNGALVIS, J.D. Detection and molecular characterization of porcine circovirus type 2 from piglets with Porcine Circovirus Associated Diseases in Colombia. Virol. J., v.11, p.1-11, 2014.

PALANIAPPAN, R.U.M.; CHANG, Y.F.; CHANG, C.F. et al. Evaluation of lig-based conventional and real time PCR for the detection of pathogenic leptospires. Mol. Cell. Probes, v.19, p.111-117, 2005.

PALINSKI, R.; PIÑEYRO, P.; SHANG, P. et al. A Novel porcine circovirus distantly related to known circoviruses is associated with porcine dermatitis and nephropathy syndrome and reproductive failure. J. Virol., v.91, p.1-13, 2017.

PESCADOR, C.A.; BANDARRA, P.M.; CASTRO, L.A. et al. Co -infection by porcine circovirus type 2 and porcine par vovirus parvovirus in aborted fetuses and stillborn piglets in southern Brazil. Pesqui. Vet. Bras., v.27, p.425429, 2007.
PHAN, T.G.; GIANNITTI, F.; ROSSOW, S. et al. Detection of a novel circovirus PCV3 in pigs with cardiac and multi-systemic inflammation. Virol. J., v.13, p.1-8, 2016.

SEGALÉS, J. Porcine circovirus type 2 (PCV2) infections: clinical signs, pathology and laboratory diagnosis. Virus Res., v.164, p.10-19, 2012.

SEGALÉS, J.; KEKARAINEN, T.; CORTEY, M. The natural history of porcine circovirus type 2 : From an inoffensive virus to a devastating swine disease? Vet. Microbiol., v.165, p.13-20, 2013.

SOARES, R.M.; DURIGON, E.L.; BERSANO, J.G.; RICHTZENHAIN, L.J. Detection of porcine parvovirus DNA by the polymerase chain reaction assay using primers to the highly conserved nonstructural protein gene, NS-1. J. Virol. Methods, v.78, p.191-198, 1999.

STRAW, B.E.; DEWEY, C.E.; WILSON, M.R. Differential diagnosis of swine diseases. Dis. Swine, p.241-286, 1999.

VARGAS, A.J.; BERNARDI, M.L.; WENTZ, I.; BORTOLOZZO, F. Que decisão tomar frente a matrizes que apresentam falhas reprodutivas : elas merecem uma nova chance? Acta Sci.Vet., v.35, p.57-62, 2007.

WOLF, V.H.G.; MENOSSI, M.; MOURÃO, G.B.; GATTI, M.S.V. Molecular basis for porcine parvovirus detection in dead fetuses Genetics and Molecular Research, v.7, p.509-517, 2008.

ZHAO, D.; WANG, X.; GAO, Q. et al. Retrospective survey and phylogenetic analysis of porcine circovirus type 3 in Jiangsu province, China, 2008 to 2017. Arch. Virol., v.163, p.25312538, 2018. 